\title{
Article \\ Prioritization of Factors Affecting Sustainability Property Improvement by Using Analytical Hierarchy Process and Important-Satisfaction Model: The Case of TAIPEI 101 Tower
}

\author{
Tse-Hsiung Lin * and Shen-Guan Shih * \\ Department of Architecture, National Taiwan University of Science and Technology, Taipei City 10607, Taiwan \\ * Correspondence: barry19660228@gmail.com (T.-H.L.); d10713007@mail.ntust.edu.tw (S.-G.S.); \\ Tel.: +886-975-101-168 (T.-H.L.)
}

check for

updates

Citation: Lin, T.-H.; Shih, S.-G. Prioritization of Factors Affecting Sustainability Property Improvement by Using Analytical Hierarchy Process and Important-Satisfaction Model: The Case of TAIPEI 101 Tower Appl. Sci. 2021, 11, 257. https:// doi.org/10.3390/app11010257

Received: 1 December 2020 Accepted: 25 December 2020 Published: 29 December 2020

Publisher's Note: MDPI stays neutral with regard to jurisdictional clai$\mathrm{ms}$ in published maps and institutional affiliations.

Copyright: (C) 2020 by the authors. Licensee MDPI, Basel, Switzerland. This article is an open access article distributed under the terms and conditions of the Creative Commons Attribution (CC BY) license (https:// creativecommons.org/licenses/by/ $4.0 /)$.
Abstract: Almost without exceptions office buildings in the world investigate the approaches of optimizing the building operation and property facilities in order to maintain the best conditions of the building from the first day of opening. For sustainable buildings, how to make continuous profit must rely on the maintenance and improvement of facilities to satisfy users. However, building managers often have trouble prioritizing improvement projects toward their sustainable objectives due to the large number of facilities that have different durability years and the importance and satisfaction of these facilities to users are also different. In the past, financial consideration was usually the only one that matters when improvement of facilities was brought up. Users feedback of satisfaction was not taken into consideration, resulting in huge expenditures did not bring in high user satisfaction. This research, by scientific analysis of the data from user feedback, applies the Analytic Hierarchy Process (AHP) using TAIPEI 101 Tower as a case study to explore the key factors affecting tenants' willingness to lease office buildings by distributing questionnaires to real estate experts. By filtering out key indicators related to property facilities that users care about, this study used Importance and Satisfaction Analysis (IS Analysis) to identify items that need urgent improvement. This innovative analysis methodology can systematically and logically find out the priority of improvement projects, assisting building managers effectively invest limited resources in projects with substantial benefit, which is helpful for sustainable property management.

Keywords: analytic hierarchy process; important-satisfaction model; TAIPEI 101; sustainability

\section{Introduction}

After cities achieve notable economic goals, they are eager to show unique masterpieces in architecture. Therefore, property such as a skyscraper is turned into a symbol of economic development, and it is also representing substantial wealth and prosperity. The accumulation of years, technology innovation and economic fluctuations exert a direct effect on the operation of property. In order to remain highly profitable in operations, the maintenance of property facilities has become an issue that owners cannot ignore. Berardi (2012) pointed out that the sustainability of buildings should include considering sustainable development in three primary aspects: economic, environmental and social [1].

For property managers, the limited resources need to be invested in projects in need of urgent improvement. However, because there is no absolute rule to follow in the selection decision, it often causes difficulties while determining the improvement projects. In contrast to ordinary buildings, an office building can be viewed as a vertical city that contains various problems concerning safety, transportation, cleaning, and energy consumption that are difficult to resolve. Office buildings with a higher number of floors tend to exhibit more issues related to safety, durability, comfort, and relatively high requirements for professional property management. Such buildings are also extensive in building structure, electrical and mechanical systems, air conditioning, and elevators. This study hopes to use 
the importance-satisfaction model to analyze the tenants' real perception and improve the prioritization of projects in property management. The owners can use this tool to focus precious resources on priority improvement projects.

In the past, the building operation did not include sustainable concept, and the real feelings of the users are often ignored. Regarding facilities maintenance, not until the facilities are damaged or malfunctioned will they be considered to be replaced. Although there are other methods to improve service quality, such as Kano model, the priority of improvement projects is not clear in these methods. This research, with the goal of sustainable operation, proposes an innovative method that takes the real feelings of building users into consideration, efficiently and logically analyzing the tenant's real cognition and listing the priority order of property management improvement projects through the important-satisfaction model. Building operators can follow this order of priority and invest their limited resources on projects that need urgent improvement.

\section{Materials and Methods}

This study uses the Taipei 101 tower as a case study. First, in-depth interviews are conducted with experts who have executed real estate projects. After collecting these experts' opinions, this research reviewed the actual cases of office leasing in Taipei 101 tower to establish indicators that affect the willingness to lease office buildings. After anonymous questionnaire survey was conducted, Delphic hierarchy process along with Analytical Hierarchy Process (Satty, 1980) was employed, constructing a framework and rankings of key factors affecting the tenant's willingness to lease.

From the above indicators, this study screened out the relevant indicators for property and facility improvements, and carried out the importance and satisfaction analysis by the interviewees based on their actual perceptions.

\subsection{Expert Interviews}

The advantage of In-Depth Interview Method is to collect all possible responses and develop integrated hypotheses from them, which will serve as the basis for future research (Bainbridge, 1989) [2].Bainbridge pointed out that even if there are not many interviewees in the interviews while using the method of In-Depth Interview, since the breadth and depth of the interviews are sufficient to provide a variety of possible answers, researchers can better grasp the respondent's complex reactions to this issue. The experts consist of representatives of management group in domestic and international enterprises. Professional consultants who have deep understanding in real estate market are also invited to participate in questionnaire surveys and interviews. Based on their professional backgrounds, two different groups are created: management group and consultant group, totaling 30 experts. Among them are 7 property management consultants, 2 senior managers of international enterprises, 8 equipment maintenance personnel. Table 1 lists the groups of experts. Hartman proposed that through anonymous written discussions, experts can be guided to reach consensus based on their professional knowledge, practical work experience, and opinions, which helps solve complex issues (Hartman, 1981) [3]. By conducting in-depth interviews with experts, we can obtain new core values that are different from conventional property facility improvement.

Table 1. Backgrounds of expert groups.

\begin{tabular}{|c|c|c|c|c|}
\hline Group & Background & No. of Experts & Percentage & Total \\
\hline \multirow{3}{*}{ Management Experts } & Taipei 101 Tower & 4 & $13.33 \%$ & \multirow{3}{*}{$23.33 \%$} \\
\hline & Domestic Enterprise & 1 & $3.33 \%$ & \\
\hline & International Enterprise & 2 & $6.67 \%$ & \\
\hline \multirow{4}{*}{ Consultant Experts } & Leasing Agent & 12 & $40.00 \%$ & \multirow{3}{*}{$76.67 \%$} \\
\hline & Appraiser & 4 & $13.33 \%$ & \\
\hline & PM Consultant & 7 & $23.34 \%$ & \\
\hline & Total & 30 & $100 \%$ & $100 \%$ \\
\hline
\end{tabular}




\subsection{Literature Review}

\subsubsection{Bid rent Function Theory}

Alonso's (1960) bid rent function theory [4], concurs with Huang and Chang (2005)'s research on office relocation of enterprises shifting in the Taipei metropolitan area [5], found that the conditions of property facilities will affect willingness to rent. Holloway and Wheeler [6] analyzed the data of top 500 enterprises from Fortune magazine to investigate the shifts of office locations in the duration from 1980 to 1987, and found that the quality of property facilities is one of the key factors. Lin (2006) [7] pointed out that physical factors such as the quality of design, building materials, facility management of the office building would affect the willingness of enterprises to rent. Based on the above works, the maintenance of property facilities is crucial for tenant satisfaction and a key factor for the success or failure of real estate operations.

\subsubsection{Delphi Method}

Delphi Method, also known as Expert Judgment Method, is one of group decisionmaking approaches, used in qualitative research. Theses experts' experience are adopted in this method to solve a specific topic through multiple rounds of feedback, thereby minimizing the difference between the experts' opinions. Above mentioned AHP is mainly employed in decision-making problems that involve uncertain situations with lots of criteria. It is used in behavioral analyst, marketing strategies plan and investment portfolios.

In 1988, Khorramshahgol and Moustakis proposed Delphi Hierarchical Procedure (DHP) [8]. This method is used to establish the hierarchy and pairwise comparison matrix, and the rest of the process is the same as Analytical Hierarchy Process (AHP). This multicriteria decision theory was developed by Thomas L., Saaty (1990) [9]. The purpose of this method is to select the correct option for the complex problems.

When there is not only one evaluation factor, multi-criteria decision-making method can simplify the complex problems. The hierarchical analysis method can not only help experts to reach a consensus, but also use standardized criteria to strengthen the credibility of the result and credibility. Not only has the advantages of the AHP, but also utilizes group decision-making model of the DHP method can reduce the difference between subjective cognitions in the construction and analysis of hierarchy and performing pairwise comparison of individuals or groups by using AHP. (Yang et al., 2005) [10].

\subsubsection{Important-Satisfaction Analysis}

Parasuraman, Zeithaml and Berry, proposed P.Z.B service quality model, and it is customer that determines the service quality. The difference between customer's expectations and actual cognition determines the standard of service quality [11].

The conceptual framework of "Importance and Satisfaction Analysis" (IS Analysis) come from another questionnaire analysis method "Importance-Performance Analysis" (IPA) [12] proposed by Martilla and James (1977). The IPA research topics focus around the quality of service, investigating how important and how well it performs a respondent (customers, consumers etc.) feels to a service. The scale used in this analysis is relative comparison in that "importance" and "performance" use exactly the same questions to measure the respondent's response. IPA is first to calculate the averages of the "importance" and "performance" of all items individually, and then divide the two-dimensional graph into four quadrants based on the averages of the "importance" and "performance" of the items. The purpose is to find out the relevant indicators that affect the company's operations, consumption goals or business models, and finally use the relative position of the item to describe the performance of this item, so as to provide researchers (such as industry, service unit) an important information of improvement priority in terms of service quality.

Typically, X-axis (horizontal axis) stands for "Performance" and Y-axis (vertical axis) stands for "Importance". Centered at the average of importance and performance of all items, the plane is divided into four quadrants. 
Area I: indicating that the degree of importance is high but the degree of performance is low. The attributes falling in this quadrant should be the focus that required urgent improvement.

Area II: indicating that both the importance and performance are high, and the attributes that fall into this quadrant should continue to be maintained (keep up the good work).

Area III: indicating that both the degree of importance and performance are low, and the attributes falling in this quadrant have a low priority.

Area IV: indicating that the importance is low and the performance is high. The attribute falling in this quadrant is possible overkill.In 1992, Graf, Hemmasi, and Nielsen (1992) [13] reconceptualized the importance-performance analysis of IPA into ImportanceSatisfaction Analysis (IS Analysis), which was different from the original IPA in that the original external strategy concept (consumers and products) is extended to internal operations. This model used in resource management application is to evaluate the importance of key indicators and cognitive satisfaction by organization members, thus it is called "Importance-Satisfaction Analysis (I-S Analysis)", as shown in Figure 1.

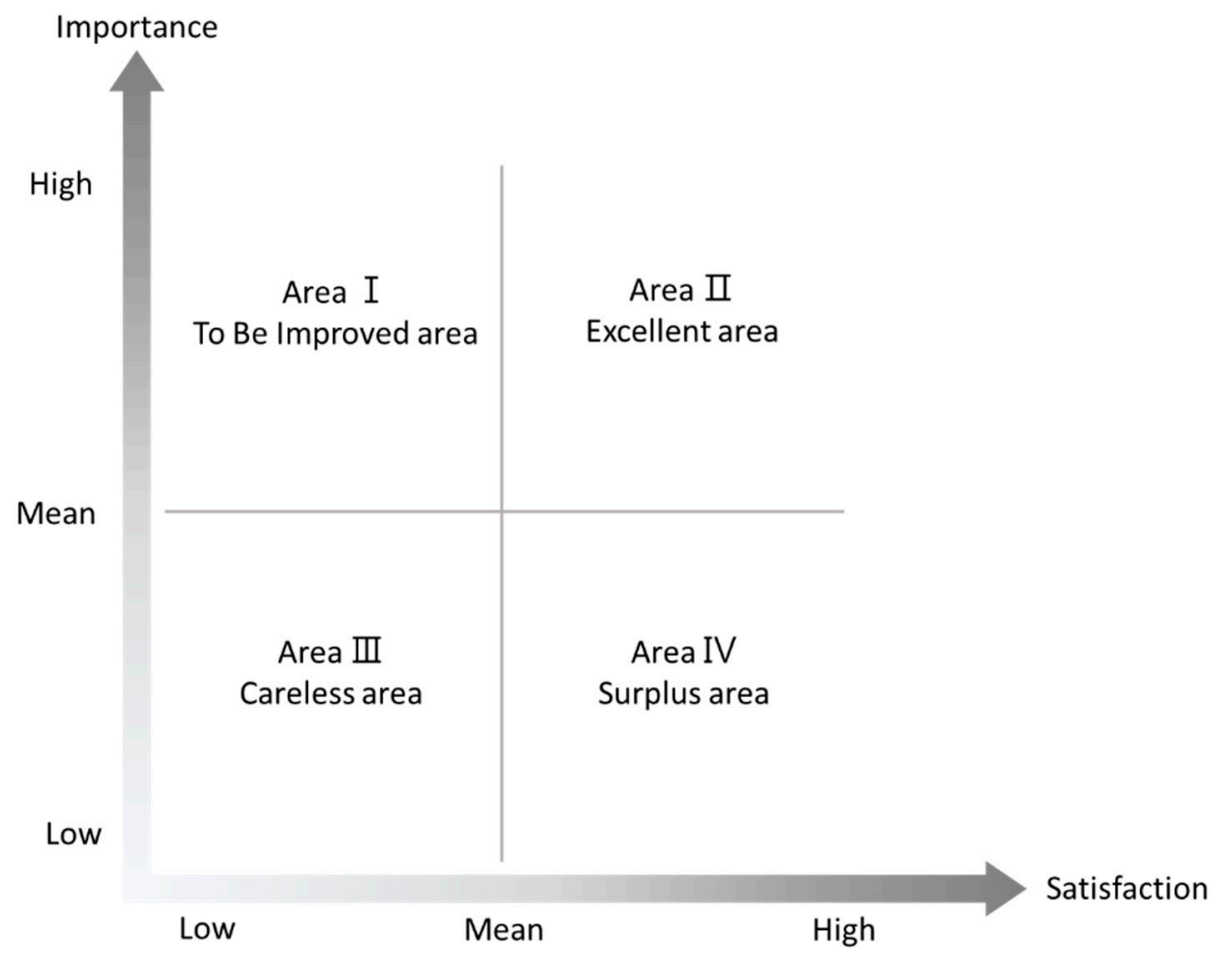

Figure 1. Importance-Satisfaction Analysis.

The first step of I-S Analysis is to complete a comprehensive list of key indicators, and through literature review and in-depth interview with experts to understand subjective experiences from these interviewees, guiding them to provide some information or express their opinions and thoughts(Henderson, 1991) [14]. Indicators can be collected by either Interviewees talk over the questions raised by the interviewers or group interviews are conducted. I-S Rating is made based on the list of the collected indicators. Interviewee would be asked to score for satisfaction rating for the key indicators on the rating scale (such as a 5-scale score, $1=$ very dissatisfied, $5=$ very satisfied), and the importance rating is also given to each key indicator. Similar to the satisfaction rating, it is rated on the scale from the "very unimportant" to the "very important". Importance and Satisfaction have different meanings. Importance refers to the importance of employees' awareness of the organization's various environmental measures, services or management factors, while satisfaction means the degree of satisfaction that employee's sense about each factor. Like IPA analysis, the average scores of importance and satisfaction are drawn into 
a two-dimensional matrix, and then the subsequent decision-making analysis is carried out according to the quadrant position of each attribute. Importance analysis can help organizations prioritize the allocation of various resources or decision-making, and satisfaction analysis can find out how satisfied respondents are with environmental facilities, services, or management. The development strategy of the indicator then can be analyzed through the quadrant of each indicator located. These high importance-high satisfaction indicators must be maintained, and these high importance-low satisfaction indicators will be focused on improvement, the low importance-low satisfaction indicators can be ignored, and the resources invested on the low importance-high satisfaction indicators can be reduced. The use of I-S Analysis quadrant graph can not only rank the improvement priority, but also provide reference for making strategy. (Sampson \& Showalter, 1999; Slack, 1994) [15].

In addition to Area I, in which items need improvement, it is worth further discussing in Area IV and the 4 parameters in this area including shopping area etc. Their importance is below the average, but respondent's satisfaction is high. Individual investigation on these items is required to clarify if there is difference in feeling between managers and users or too much resource is invested on relatively unimportant projects. For example, shopping area is an unexpected benefit for office building users, so satisfaction is high. However, it is relatively unimportant from the perspective of office use. The parameters in Area IV area in I-S Model Analysis are very noteworthy in terms of sustainable operation of buildings.

\section{Results}

\subsection{AHP \& DHP Weighting and Ranking}

The comprehensive evaluation method and system of sustainable buildings can be applied to the considerations of pre-design, building construction, management operation, facility maintenance of sustainable buildings to the end of life of main building (Vierra, 2015) [16]. This study takes Taipei 101 Tower, once the tallest building in the world, as a research case. Through in-depth interviews, based on years of work experience and insights in the professional field, experts put forward their own opinions. After sorting out the factors that affect the willingness to rent, there are a total of 5 aspects and 25 key factors, as shown in Table 2.

We used both of AHP and Delphi methods for questionnaire verification, and then calculated the weights of core indicators. Total of 40 expert questionnaires were sent, 36 questionnaires responded, finally there are 26 were effective (see Table 3 ).

The return rate of questionnaire was $90 \%$, with the effective questionnaire data consistency ratio $(C R) \leq 0.1$, and all data are included in the statistics. On the first level, sort order by weight are " Geographical location 29.99\%", "Transportation convenience 24.25\%", "Image 20.41\%", "Building Facilities 15.06\%" and " Nearby facilities 10.29\%". The overall weights and ranking of indicators are listed in Table 4. 
Table 2. Indicators affecting the leasing willingness.

\begin{tabular}{|c|c|c|}
\hline Goal & Level 1 & Level 2 \\
\hline \multirow{5}{*}{$\begin{array}{l}\text { Indicators affecting the } \\
\text { leasing willingness }\end{array}$} & Building facilities & $\begin{array}{l}\text { 1. Height of ceiling } \\
\text { 2. Defense of earthquake } \\
\text { 3. High-Level materials } \\
\text { 4. Independent A/C } \\
\text { 5. Backup power }\end{array}$ \\
\hline & Geographical location & $\begin{array}{l}\text { 6. Central Business district } \\
\text { 7. Shopping area } \\
\text { 8. Dining selections } \\
\text { 9. Zoning } \\
\text { 10. Recreational area }\end{array}$ \\
\hline & Nearby facilities & $\begin{array}{l}\text { 11. Common Facilities } \\
\text { 12. Service amenities } \\
\text { 13. Dual power } \\
\text { 14. Healthcare support } \\
\text { 15. Hotel selections }\end{array}$ \\
\hline & Transportation convenience & $\begin{array}{l}\text { 16. Metro stations } \\
\text { 17. Highway interchanges } \\
\text { 18. Car Parking } \\
\text { 19. Public transit } \\
\text { 20. Road networks }\end{array}$ \\
\hline & Image & $\begin{array}{l}\text { 21. Landmark building } \\
\text { 22. Green and smart building } \\
\text { 23. Tenant portfolio } \\
\text { 24. Image of Owner } \\
\text { 25. Property management }\end{array}$ \\
\hline
\end{tabular}

Table 3. Background of Experts.

\begin{tabular}{ccccc}
\hline Group & Type & $\begin{array}{c}\text { Distributed } \\
\text { Copies }\end{array}$ & $\begin{array}{c}\text { Returned } \\
\text { Copies }\end{array}$ & $\begin{array}{c}\text { Valid } \\
\text { Copies }\end{array}$ \\
\hline \multirow{2}{*}{$\begin{array}{c}\text { Management } \\
\text { group }\end{array}$} & Finance & 5 & 4 & 4 \\
& Engineering & 5 & 5 & 1 \\
Building Management & 5 & 5 & 2 \\
Consultant & Leasing agency & 10 & 10 & 10 \\
group & Appraiser & 5 & 5 & 4 \\
& PM consultant & 10 & 7 & 5 \\
\hline
\end{tabular}

Table 4. AHP ranking of the weighted indicators.

\begin{tabular}{clcc}
\hline \multicolumn{1}{c}{ Level 1 } & \multicolumn{1}{c}{ Level 2 } & Cumulative Weight & Rank \\
\hline & 1. Height of ceiling & $1.17 \%$ & 25 \\
Building Facilities & 2. Defense of earthquake & $3.22 \%$ & 10 \\
$15.06 \%$ & 3. High-Level building materials & $1.30 \%$ & 14 \\
& 4. Independent A/C & $2.37 \%$ & 20 \\
& 5. Backup power & $2.69 \%$ & 16 \\
\hline \multirow{2}{*}{ Geographical location } & 6. Central Business district & $11.57 \%$ & 1 \\
$29.99 \%$ & 7. Shopping area & $3.12 \%$ & 11 \\
& 8. Dining selections & $7.46 \%$ & 4 \\
& 9. Zoning & $3.54 \%$ & 9 \\
& 10. Recreational area & $2.67 \%$ & 17 \\
\hline
\end{tabular}


Table 4. Cont.

\begin{tabular}{clcc}
\hline Level 1 & \multicolumn{1}{c}{ Level 2 } & Cumulative Weight & Rank \\
\hline & 11. Common Facilities & $2.84 \%$ & 14 \\
Nearby facilities & 12. Service amenities & $2.83 \%$ & 15 \\
$10.29 \%$ & 13. Dual power & $2.48 \%$ & 18 \\
& 14. Healthcare support & $1.49 \%$ & 23 \\
& 15. Hotel selections & $1.78 \%$ & 22 \\
\hline \multirow{2}{*}{ Transportation } & 16. Metro stations & $9.97 \%$ & 2 \\
convenience & 17. Highway interchanges & $2.26 \%$ & 21 \\
$24.25 \%$ & 18. Car Parking & $4.03 \%$ & 8 \\
& 19. Transportation & $6.29 \%$ & 5 \\
& 20. Road networks & $3.12 \%$ & 12 \\
\hline & 21. Landmark building & $7.65 \%$ & 3 \\
Image & 22. Green and smart building & $2.92 \%$ & 13 \\
$20.21 \%$ & 23. Tenant portfolio & $4.98 \%$ & 7 \\
& 24. Image of Owner & $2.38 \%$ & 19 \\
\hline $100 \%$ & 25. Property management & $5.88 \%$ & 6 \\
\hline
\end{tabular}

\subsection{External and Internal Key Indicators}

Through AHP and DHP analysis, the sort order of 25 key indicators affecting leasing willingness is derived. Key indicators can be divided into external and internal indicators as shown in Table 5. Among them, the external indicators belong to the projects that cannot be improved by property management unit alone. The improvement of internal indicators will help increase the willingness to rent, thus the operation of sustainable buildings will be more stable due to the increase in user satisfaction.

The importance and satisfaction of property facilities were analyzed based on 16 internal indicators. 25 respondents rated 16 key indicators following Likert Scale [17]. Importance and satisfaction scores of each indicator are shown in Table 6.

The distribution of internal indicators based on the scores of importance and satisfaction is illustrated in Figure 2.

Table 5. External and internal key indicators.

\begin{tabular}{|c|c|c|}
\hline Type & Key Indicators & Description \\
\hline \multirow{10}{*}{ External } & 1. Central business district & Located in the main business district of Taipei City \\
\hline & 2. Recreational space & Close to recreational space such as Xinyi \\
\hline & 3. Common facilities & $\begin{array}{l}\text { Sports Center } \\
\text { Nearby area provides a full range of necessary } \\
\text { public facilities }\end{array}$ \\
\hline & 4. Healthcare support & $\begin{array}{l}\text { Close to medical resources such as hospital in case } \\
\text { of emergency }\end{array}$ \\
\hline & 5. Hotel selections & Adjacent to star-rated hotels providing \\
\hline & 5. Hotel selections & Accommodation options for foreign visitors \\
\hline & 6. Metro stations & $\begin{array}{l}\text { The building is connected to the exit of the } \\
\text { MRT station }\end{array}$ \\
\hline & 7. Highway interchanges & Connectivity to the highway interchange. \\
\hline & 8. Transportation & Public transit is convenient around the building \\
\hline & 9. Road networks & Connectivity to complete road networks \\
\hline
\end{tabular}


Table 5. Cont.

\begin{tabular}{|c|c|c|}
\hline Type & Key Indicators & Description \\
\hline \multirow{16}{*}{ Internal } & 1. Height of ceiling & Indoor ceiling height exceeds 2.8 meters \\
\hline & 2. Defense of earthquake & $\begin{array}{l}\text { Various seismic equipment including } \\
\text { wind dampers }\end{array}$ \\
\hline & $\begin{array}{l}\text { 3. High-Level } \\
\text { building materials }\end{array}$ & high quality building materials used in building \\
\hline & 4. Independent A/C & $\begin{array}{l}\text { Independent air conditioning equipment provided } \\
\text { by the owner }\end{array}$ \\
\hline & 5. Backup power & Backup power supply in case of emergency \\
\hline & 6. Shopping area & Adjacent to shopping district \\
\hline & 7. Dining selections & Numerous dining options nearby \\
\hline & 8. Zoning & $\begin{array}{l}\text { Land use zoning is legal for company } \\
\text { establishment and registration }\end{array}$ \\
\hline & 9. Service amenities & $\begin{array}{l}\text { Provides complete business supporting amenities } \\
\text { such as convenience store, express and } \\
\text { dry cleaning }\end{array}$ \\
\hline & 10. Dual power & $\begin{array}{l}\text { The building has the power supply from } \\
\text { Taipower's dual power substation }\end{array}$ \\
\hline & 11. Car parking & $\begin{array}{l}\text { The building provides sufficient parking spaces for } \\
\text { tenants and visitors }\end{array}$ \\
\hline & 12. Landmark Building & $\begin{array}{l}\text { The building itself is an internationally renowned } \\
\text { landmark building }\end{array}$ \\
\hline & 13. Green and smart building & $\begin{array}{l}\text { The building is designed or operated as green } \\
\text { buildings and smart buildings }\end{array}$ \\
\hline & 14. Tenant portfolio & High quality tenant mix \\
\hline & 15. Image of Owner & The building has a good social image \\
\hline & 16. Property management & $\begin{array}{l}\text { Owners provide high quality } \\
\text { property management }\end{array}$ \\
\hline
\end{tabular}

Table 6. Importance and satisfaction scores of internal key indicators.

\begin{tabular}{lcc}
\hline \multicolumn{1}{c}{ Key Indicators } & Importance & Satisfaction \\
\hline 1. Height of ceiling & 4.3667 & 3.6000 \\
2. Defense of earthquake & 4.3667 & 4.6333 \\
3. High-Level building materials & 3.8667 & 3.6667 \\
4. Independent A/C & 4.3667 & 3.0000 \\
5. Backup power & 4.6333 & 3.8333 \\
6. Shopping area & 3.8333 & 4.3333 \\
7. Dining selections & 4.3000 & 4.0000 \\
8. Zoning & 4.1667 & 3.9000 \\
9. Service amenities & 4.4333 & 4.4333 \\
10. Dual power & 4.4333 & 3.8000 \\
11. Car parking & 4.7000 & 3.9667 \\
12. Landmark Building & 4.4000 & 4.3000 \\
13. Green and smart building & 3.9667 & 3.8000 \\
14. Tenant portfolio & 4.5667 & 3.8000 \\
15. Image of Owner & 3.8000 & 3.9000 \\
16. Property management & 4.6667 & 4.3667 \\
\hline
\end{tabular}




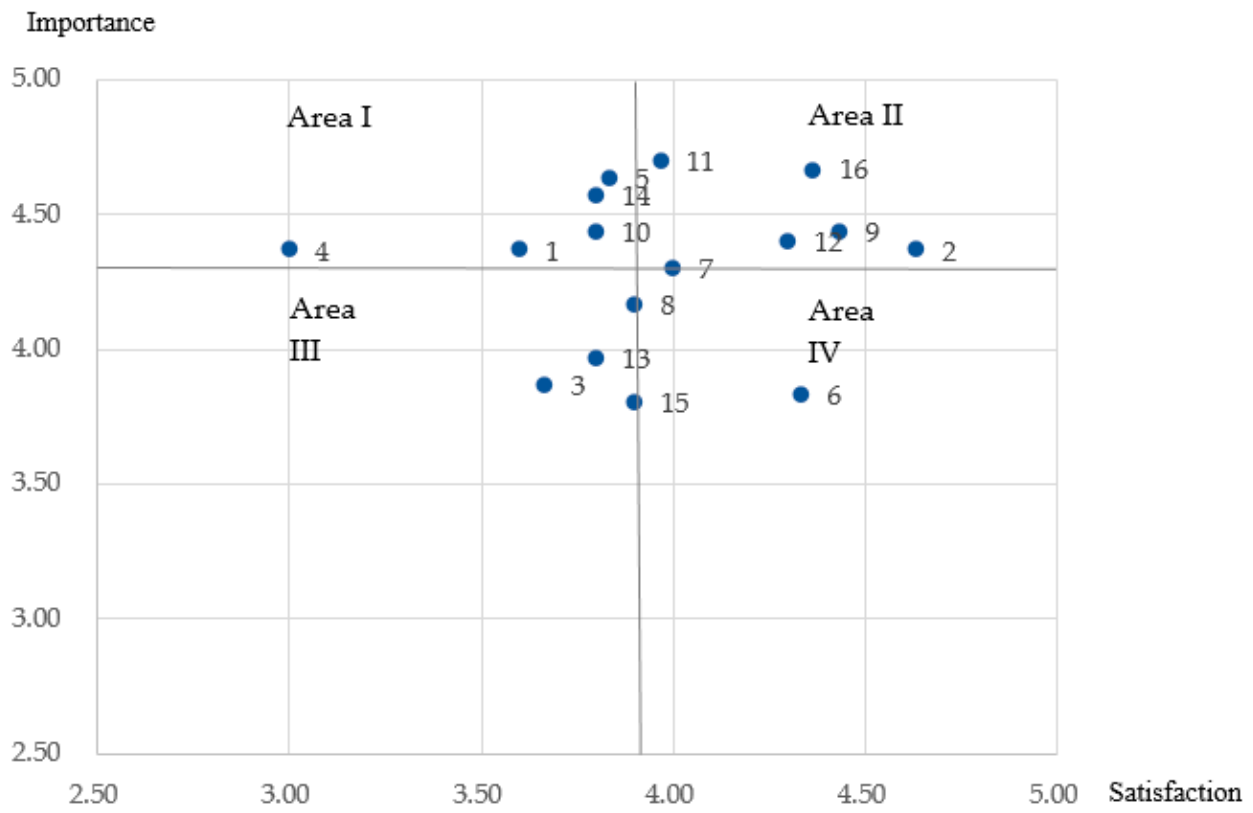

Figure 2. Importance-Satisfaction Distribute Analysis.

\section{Discussion}

Uher \& Lawson (1998) pointed out that specific environmental problems need to rely on the performance standards and indicators of sustainable building to evaluate the performance of buildings or facilities [18]. Sustainable building is the creation and the practice of reconstruction, operation, maintenance, and demolition of architecture models using healthier and more resource-efficient construction methods (Roy, 2008) [19]. In this case study, based on the analysis of I-S Model, there are 5 items fell in Area I(To be Improved Area); 6 items fell in Area II (Excellent Area); 4 items fell in Area III (Careless Area); 1 items in Area IV (Surplus Area). Key indicators are listed in Table 7.

Table 7. I-S Model Interanl key indicators distributed area.

\begin{tabular}{cc}
\hline Area I & Area II \\
\hline Height of ceiling & Dining selections \\
Independent A/C & Car parking \\
Backup power & Defense of earthquake \\
Dual power & Service amenities \\
Tenant portfolio & Landmark building \\
Area III & Property management \\
\hline $\begin{array}{c}\text { High-Level building materials } \\
\text { Green and smart building } \\
\text { Zoning } \\
\text { Image of owner }\end{array}$ & Area IV \\
\hline
\end{tabular}

In Area I (To be Improved Area), there are 5 items that need to be improved first in this study. Among them, the most urgent item of property facilities to be improved is air-conditioning facilities. The importance is high but the satisfaction is low. After in-depth investigation, it is found that regarding the interviewees are mainly dissatisfied with the air-conditioning facilities, suggested solutions for the improvement order can refer to Yang's proposal (2003), between importance and satisfaction using improvement coefficient method [20] to calculate the difference ratio The greater the negative value, the higher the priority to improve. 
The formula is as follows:

$$
\text { Improvement coefficient }=\frac{(\text { customer satisfaction }- \text { customer importance })}{\text { customer importance }}
$$

\section{Conclusions}

The value of the building starts from the day of completion, and the life span of the building will depend on the maintenance and management of the property facilities. Berardi (2012) has pointed out that building's sustainability should consider sustainable development in three primary aspects: economic, environmental and social, while also meeting functional performance requirements. Achieving sustainable architecture is one of the main objectives for humans to create a better life and an ultimate model for professional activities. Hence, moving forward to a greener architecture is one of the primary goals for modern architecture in our time (Mahdavinejad, Arash, Airya, Setareh \& Narjes, 2014) [21].

Enterprises usually operate with limited resources, the same situation as the sustainable operation and management of buildings. When faced with increasingly sophisticated construction methods and continuous advancement of equipment for property and facility management, there is no particular rule to follow in the past. In the face of inadequate resources, the order of improvement projects often depends on the project budget required. Such an arrangement may not meet users' expectations, and huge costs are invested in ineffective property and facility improvements; however, the user's satisfaction cannot be improved afterward, ultimately leading to poor operations. This study provided the basis for the advancement of property facilities through the selection process of key indicators and the analysis method of the user's importance and satisfaction, and a practical framework for the decision making of property managers and owners.

Author Contributions: Conceptualization, T.-H.L. and S.-G.S.; writing—original draft preparation, T.-H.L.; writing-review and editing, T.-H.L. and S.-G.S. All authors have read and agreed to the published version of the manuscript.

Funding: This research received no external funding.

Institutional Review Board Statement: Not applicable.

Informed Consent Statement: Not applicable.

Data Availability Statement: The data presented in this study is contained in the article itself.

Conflicts of Interest: The authors declare no conflict of interest.

\section{References}

1. Berardi, U. Sustainability assessment in the construction sector: Rating Systems and Rated Buildings. Sustain. Dev. 2012, 20, 411-424. [CrossRef]

2. Bainbridge, W.S. Survey Research: A Qualitative Approach to Recreation, Parks, and Leisure Research; Venture: Stage College, PA, USA, 1989.

3. Hartman, A. Reaching consensus using the Delphi technique. Educ. Leadersh. 1981, 38, 495-497.

4. Alonso, W. Big Rent Function Theory. 1960. Available online: https://www.sjsu.edu/faculty/watkins/alonso.htm (accessed on 1 December 2020).

5. Huang, M.Y.; Chang, C.O. Office location shifts of large-scale enterprises in Taipei metropolitan area. Manag. Rev. 2005, $24,83-102$.

6. Holloway, S.R.; Wheeler, J.O. Corporate headquarters relocation and changes in metropolitan corporate dominance, $1980-1987$. Econ. Geogr. 1991, 67, 52-72. [CrossRef]

7. Lin, Y.Y. Real-Estate Appraisal Q\&A (Wensheng Book Store, Taipei). Personal communication, 2006.

8. Khorramshahgol, R.; Moustakis, V.S. Delphic hierarchy process (DHP): A methodology for priority setting derived from the Delphi method and analytical hierarchy process. Eur. J. Oper. Res. 1988, 37, 347-354. [CrossRef]

9. Saaty, T.L. How to make a decision: The analytic hierarchy process. Eur. J. Oper. Res. 1990, 48, 9-21. [CrossRef]

10. Yang, D.J.; Chen, Y.; Yeh, C.L. The Establishment and Evaluation of Sustainable Development Indicator of Taiwan Fishery. J. Public Aff. Rev. 2005, 6, 76-110.

11. Parasuraman, A.; Zeithaml, V.A.; Berry, L. Problems and Strategies in Services Marketing. J. Mark. 1985, $49,33-46$.

12. Martilla, J.A.; James, J.C. Importance-performance analysis. J. Mark. 1977, 41, 77-79. [CrossRef] 
13. Graf, L.A.; Hemmasi, M.; Nielsen, W. Importance-satisfaction analysis: A diagnostic tool for organizational change. Leadersh. Organ. Dev. J. 1992, 13, 8-12. [CrossRef]

14. Henderson, K.A. Dimensions of Choice: A Qualitative Approach to Recreation, Park, and Leisure Research; Venture: Stage College, PA, USA, 1991.

15. Sampson, S.E.; Showalter, M.J. The Performance-Importance Response Function: Observations and Implications. Serv. Ind. J. 1999, 19, 1-25. [CrossRef]

16. Vierra, S. Green Building Standards and Certification Systems. Available online: https://www.wbdg.org/resources/greenbuilding-standards-and-certification-systems (accessed on 5 August 2019).

17. Likert, R. A technique for the measurement of attitudes. Arch. Psychol. 1932, 22, 5-55.

18. Uher, T.E.; Lawson, W. Sustainable Development in Construction. In Proceedings of the 14th CIB World Building Congress on Construction and the Environment, Gavle, Sweden, 7-12 June 1998.

19. Roy, M. Importance of Green Architecture Today, of Architecture; Jadavpur University: Kolkata, India, 2008.

20. Yang, C.C. Establishment and applications of the integrated model of service quality measurement. Manag. Serv. Qual. 2003, 13, 310-324. [CrossRef]

21. Mahdavinejad, M.; Arash, Z.; Airya, N.; Setareh, G.; Narjes, E. Dilemma of green and pseudo green architecture based on LEED norms in case of developing countries. Int. J. Sustain. Built Environ. 2014, 3, 235-246. [CrossRef] 